\title{
Archaean U-Pb zircon ages from the Scoresby Sund region, East Greenland
}

\author{
B. T. Hansen, A. K. Higgins and B. Borchardt
}

\begin{abstract}
$\mathrm{U}-\mathrm{Pb}$ analyses on zircons are reported for two rock collections from infracrustal complexes within the East Greenland Caledonian fold belt in the Scoresby Sund region. Calculated minimum ages range from 2800 to $2965 \mathrm{Ma}$, and are the oldest ages obtained in the region using this method.

B. T. H. \& B. B., Institut für Mineralogie, Universität Münster, Corrensstrasse 24, D-4400 Münster, Germany.

A. K. H., Grønlands Geologiske Undersegelse, Oster Voldgade 10, DK-1350 Copenhagen K, Denmark.
\end{abstract}

\section{Introduction}

Exposures of gneissic infracrustal complexes are widespread in the western part of the Scoresby Sund region (fig. 1), and make up the oldest rock units within the southern part of the East Greenland Caledonian fold belt. In some areas the rocks of the infracrustal complexes give Archaean isotopic ages and appear to have been relatively unaffected by younger events, whereas elsewhere they have been strongly deformed by Grenville (c. 1100 $\mathrm{Ma})$ or Caledonian orogenic events.

The most widespread infracrustal unit in the Scoresby Sund region is known as the Flyverfjord infracrustal complex (Henriksen \& Higgins, 1976; Henriksen et al. 1980; Higgins, 1982). It is dominated by strongly folded, banded gneisses with abundant amphibolite bands and ultrabasic lenses and with, characteristically, discordant amphibolitic dykes. A variety of foliated granites and migmatitic granites are associated with the gneisses and are folded together with them; they are interpreted as an early phase of intrusions.

One of the earliest isotopic ages reported from the Flyverfjord infracrustal complex was a $\mathrm{Rb}-\mathrm{Sr}$ whole rock isochron age of $2935 \mathrm{Ma}$ on leucocratic gneisses from Flyverfjord (Rex \& Gledhill, 1974). Subsequently, Steiger et al. (1979) reported a zircon age of $2300 \mathrm{Ma}$ on a foliated granite north of Nordvestfjord, a zircon age of $2520 \mathrm{Ma}$ on granitic augen gneiss around Harefjord, and a K-Ar hornblende age of $2511 \mathrm{Ma}$ from a discordant amphibolite south of Flyverfjord.

\section{Sampling and analytical procedure}

Sample collections, on which the new zircon analyses were performed, were taken from infracrustal complexes at two localities, one in Charcot Land and the other at the head of Harefjord (fig. 1). Fresh and homogeneous material was obtained by drilling and blasting, and in each case about $100 \mathrm{~kg}$ of rock was collected.

The U-Pb analyses were performed according to the procedure described by Persson et al. (1973). Age calculations were made using the constants recommended by the IUGS Subcommission (Steiger \& Jäger, 
1977). Errors based on replicate analyses are $0.7 \%$ for the ${ }^{207} \mathrm{~Pb} /{ }^{235} \mathrm{U}$ ratio and $0.4 \%$ for the ${ }^{206} \mathrm{~Pb} /{ }^{235} \mathrm{U}$ and ${ }^{207} \mathrm{~Pb} /{ }^{206} \mathrm{~Pb}$ ratios. Regression lines were calculated according to the least squares method of York (1969). Errors quoted are $2 \sigma$ of the mean.

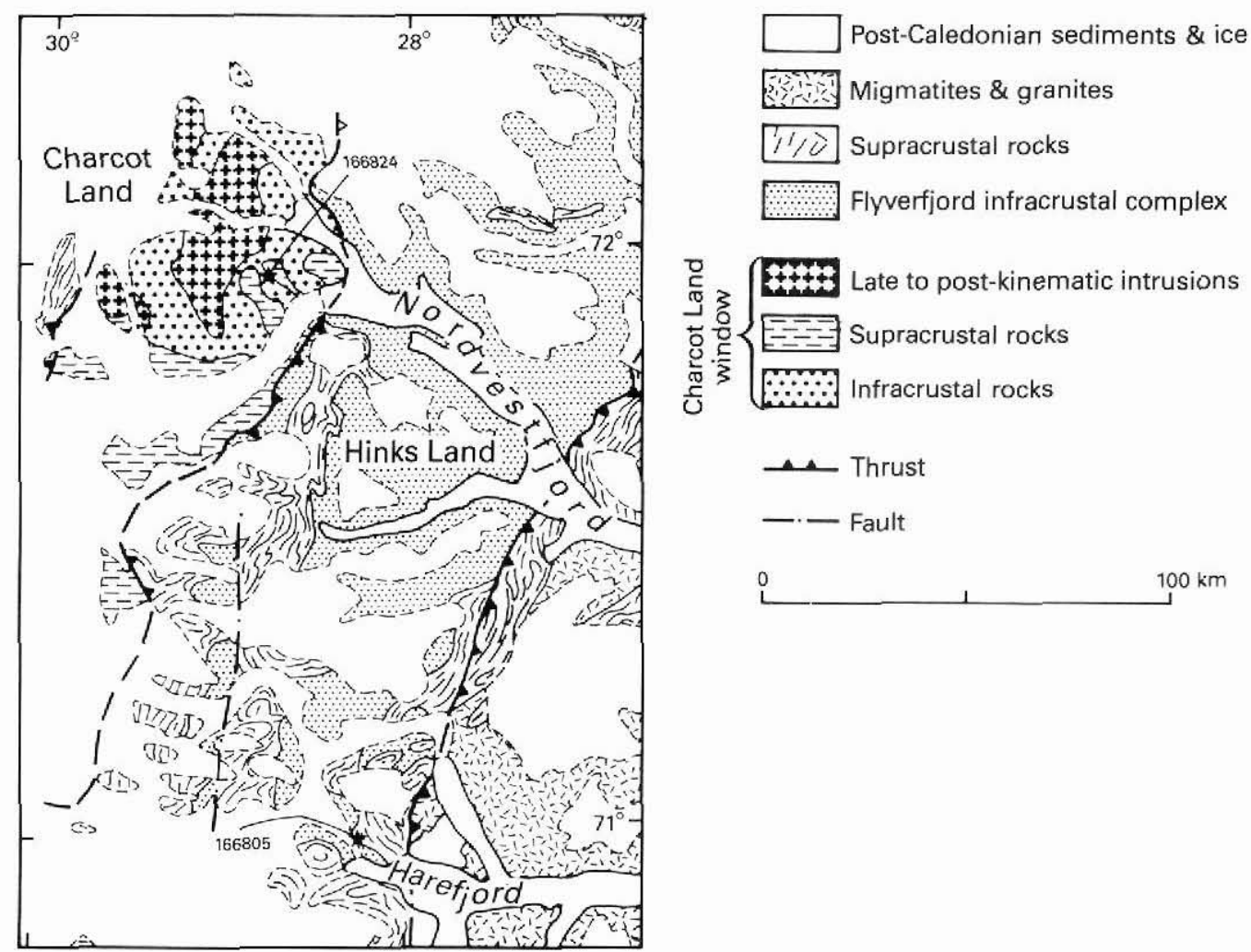

Fig. 1. Simplified geological map of the area between Charcot Land and Harefjord, showing sample localities.

\section{Charcot Land}

Most of Charcot Land, together with adjacent nunataks and part of western Hinks Land, occur in a tectonic window below an arch-shaped thrust with a westward displacement of at least $40 \mathrm{~km}$. The rock units within the window include: (1) an infracrustal complex of gneisses and granites, (2) the Charcot Land supracrustal sequence, (3) late to post-kinematic intrusions, and (4) a small occurrence of tillite. The general geology of the region is described by Henriksen \& Higgins (1976) and Higgins (1982), and a study of metamorphism of the supracrustal rocks by Steck (1971).

Previous isotopic studies (Hansen et al., 1981) led to the following chronology for the rock units of the Charcot Land window. The infracrustal complex has yielded K-Ar hornblende ages of $2855 \mathrm{Ma}, 2097 \mathrm{Ma}, 2075 \mathrm{Ma}, 1750 \mathrm{Ma}$ and $642 \mathrm{Ma}$; some of these ages reflect 
metamorphic overprinting, and it was concluded that the age of the complex was greater than $2100 \mathrm{Ma}$ and probably Archaean. It was compared in general terms to the Flyverfjord infracrustal complex. U-Pb studies on zircons from a metagabbro body of the Charcot Land supracrustal sequence suggest a main metamorphic event probably 1900-1850 Ma ago. A $\mathrm{Rb}-\mathrm{Sr}$ whole rock isochron age on a pegmatite granite suggests probable intrusion $1850 \mathrm{Ma}$ ago, while a similar age (c. $1840 \mathrm{Ma}$ ) was obtained by U-Pb analyses on zircons from a hornblende-biotite quartz diorite intrusion. There is no isotopic or fossil evidence for the age of the tillite, which overlies $1840 \mathrm{Ma}$ intrusions and lies beneath a Caledonian thrust, but it is thought likely to be latest Precambrian (Henriksen, 1981).

Table 1. U-Pb analytical data on zircons from the Scoresby Sund region

\begin{tabular}{|c|c|c|c|c|c|c|c|c|c|c|}
\hline \multirow{2}{*}{$\begin{array}{l}\text { GGU sample } \\
\text { No \& sieve } \\
\text { fraction } \\
\text { in } \mu \mathrm{rn}\end{array}$} & \multirow{2}{*}{$\begin{array}{l}\text { mg sample } \\
\text { analysed }\end{array}$} & \multicolumn{3}{|c|}{ Observed atomic ratios } & \multirow{2}{*}{$\begin{array}{c}\mathrm{U} \\
\mathrm{ppm}\end{array}$} & \multirow{2}{*}{$\begin{array}{l}\mathrm{Pb}_{\mathrm{rad}} \\
\mathrm{ppm}\end{array}$} & \multirow{2}{*}{$\begin{array}{l}{ }^{206} \mathrm{~Pb}_{\mathrm{rad}} \\
\mathrm{n} \mathrm{mol} / \mathrm{g}\end{array}$} & \multicolumn{3}{|c|}{$\begin{array}{l}\text { Atomic ratios corrected for } \\
\text { blank* and common } \mathrm{Pb}\end{array}$} \\
\hline & & $\frac{{ }^{208} \mathrm{~Pb}}{206 \mathrm{~Pb}}$ & $\frac{207 \mathrm{~Pb}}{206 \mathrm{~Pb}}$ & $\frac{{ }^{206} \mathrm{~Pb}}{{ }^{204} \mathrm{~Pb}}$ & & & & $\begin{array}{c}\text { blank } \\
\frac{206 \mathrm{~Pb}}{238 \mathrm{U}}\end{array}$ & $\begin{array}{l}{ }^{*} \text { and com } \\
\frac{{ }^{207} \mathrm{~Pb}}{{ }^{235} \mathrm{U}}\end{array}$ & $\begin{array}{l}\text { non } \mathrm{Pb} \\
\qquad \frac{207 \mathrm{~Pb}}{206 \mathrm{~Pb}}\end{array}$ \\
\hline \multicolumn{11}{|l|}{$G G U 166805$} \\
\hline$<40$ & 2.2 & 0.06901 & 0.19536 & 1718 & 650 & 315 & 1236 & 0.45550 & 11.8254 & 0.18829 \\
\hline $40-63$ & 6.85 & 0.03474 & 0.19319 & 7874 & 854 & 324 & 1286 & 0.36086 & 9.5361 & 0.19166 \\
\hline $63-80$ & 5.0 & 0.03436 & 0.19257 & 8065 & 882 & 329 & 1306 & 0.35484 & 9.3478 & 0.19106 \\
\hline $80-125$ & 6.7 & 0.03131 & 0.18266 & 5155 & 1117 & 349 & 1403 & 0.30101 & 7.4912 & 0.18050 \\
\hline$>125$ & 6.65 & 0.02715 & 0.16526 & 2801 & 1828 & 455 & 1875 & 0.24589 & 5.4502 & 0.16076 \\
\hline \multicolumn{11}{|c|}{$G G U 166824>75 \mu$} \\
\hline grey, round & 1.1 & 0.56893 & 0.20744 & 70 & 2106 & 131 & 591 & 0.06686 & 0.58304 & 0.06325 \\
\hline milky, prism. & 0.1 & 0.25253 & 0.15224 & 178 & 4167 & 288 & 1300 & 0.07176 & 0.71060 & 0.07182 \\
\hline clear, idiom. & 0.25 & 0.17134 & 0.12901 & 251 & 1552 & 118 & 520 & 0.08103 & 0.80334 & 0.07190 \\
\hline milky, round & 0.5 & 0.16086 & 0.11994 & 265 & 2995 & 191 & 860 & 0.06829 & 0.61806 & 0.06564 \\
\hline green, prism. & 0.7 & 0.18489 & 0.11842 & 279 & 2592 & 175 & 757 & 0.07004 & 0.64614 & 0.06691 \\
\hline
\end{tabular}

* Composition of lead used for blank correction ${ }^{206} \mathrm{~Pb} /{ }^{204} \mathrm{~Pb}=18.7,{ }^{208} \mathrm{~Pb} /{ }^{204} \mathrm{~Pb}=15.63$, ${ }^{208} \mathrm{~Pb} /{ }^{204} \mathrm{~Pb}=38.63$

The composition of common lead used for correction accords to the model of Stacey \& Kramers (1975).

To establish better age control for the infracrustal rocks, U-Pb analyses have been carried out on zircons from a large sample of quartzo-feldspathic gneiss (GGU sample no. 166824); the small proportion of mafic minerals comprise mainly biotite. Five zircon fractions, all from the sieve fraction $>75 \mu$, have been analysed; the data are given in Table 1 and plotted in fig. 2 . The zircons show a variety of habits and colour, including clear idiomorphic, milky prismatic, light green prismatic, grey rounded and milky rounded. Four fractions (excluding the clear idiomorphic zircons) define a discordia with a lower intercept at $403 \mathrm{Ma}$ and an upper intercept at $2813 \mathrm{Ma}$ (fig. 2). Because of the extended extrapolation and the very low ${ }^{206} \mathrm{~Pb} /{ }^{204} \mathrm{~Pb}$ ratios $(70-300$, Table 1$)$ the older age is uncertain. However, an age of about $2800 \mathrm{Ma}$ is in agreement with the K-Ar hornblende age on an amphibolite from the Charcot Land infracrustal complex (Hansen et al., 1981), as well as with ages obtained on the similar rocks of the Flyverfjord infracrustal complex (Rex \& Gledhill, 1974; Steiger et al., 1979). The high discordancy is probably related to episodic lead loss due to tectonic overprinting during 


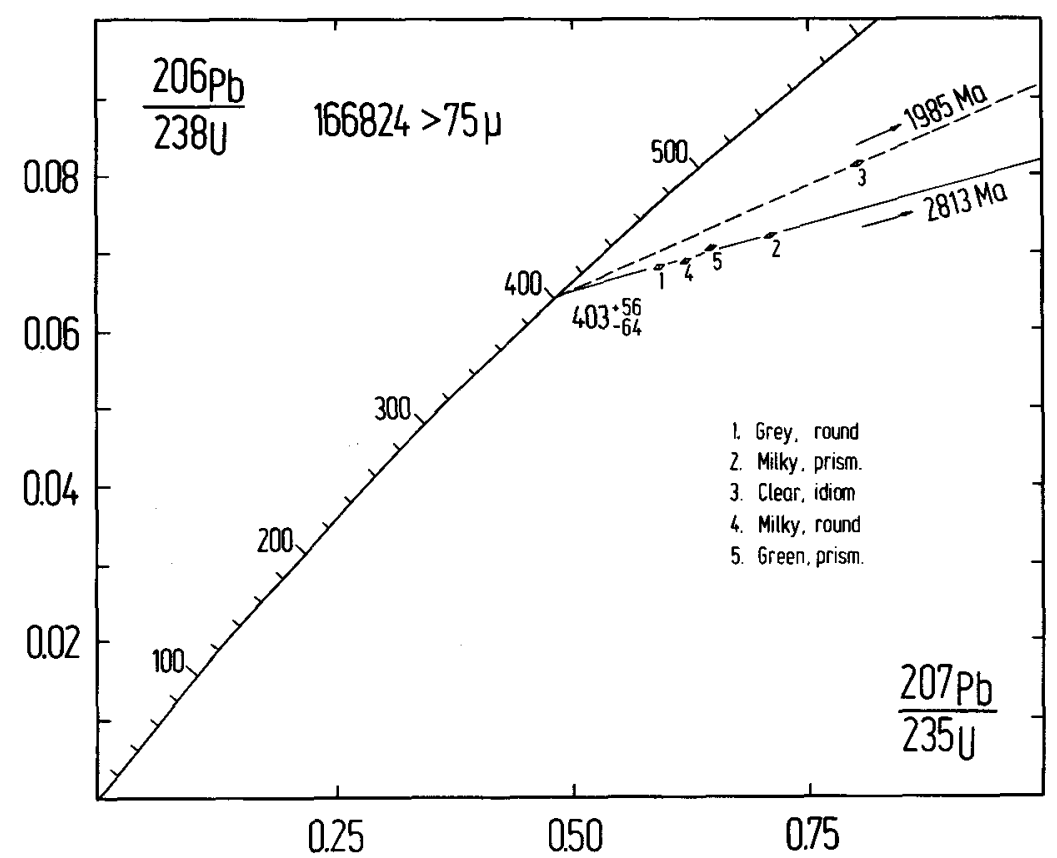

Fig. 2. Concordia plot of zircons from sample 166824, Charcot Land.

the Caledonian orogeny rather than to new growth, as Caledonian metamorphism was only of retrogressive character in the Charcot Land window.

The data point for the clear idiomorphic zircon fraction falls clearly above the discordia defined by the other four fractions (fig. 2). A tieline between this point and $400 \mathrm{Ma}$ gives an upper intercept of $1985 \mathrm{Ma}$. This age is coincident with the age for the main regional metamorphism of the Charcot Land supracrustal sequence (c. 1850-1900 Ma; Hansen et al., 1981) and could be explained by new zircons grown during this event suffering episodic lead loss during Caledonian time. If new zircon growth did take place at this time then the discordia age of $2800 \mathrm{Ma}$ deduced from the other four zircon fractions is a minimum age, as all fractions would have been displaced towards the discordia by new growth during the $1900 \mathrm{Ma}$ event. While this interpretation is speculative in view of the high discordance of the analysed fractions, it is of interest that the upper intercept ages agree with known events in the area.

\section{Harefjord}

Infracrustal rocks outcropping around the head of Harefjord include banded gneisses with amphibolite layers and lenses, and a homogeneous biotite augen gneiss with sharp boundaries to the banded gneisses and probably of igneous origin. These infracrustal rocks can be traced discontinuously northwards into the more extensive exposures of infracrustal rocks around Flyverfjord (fig. 1), and may be viewed as part of the same complex.

Analyses of zircons from the homogeneous augen gneiss by Steiger et al. (1979) suggest an age of formation (or intrusion) at $2510 \mathrm{Ma}$. Additional analyses, reported here, have been 


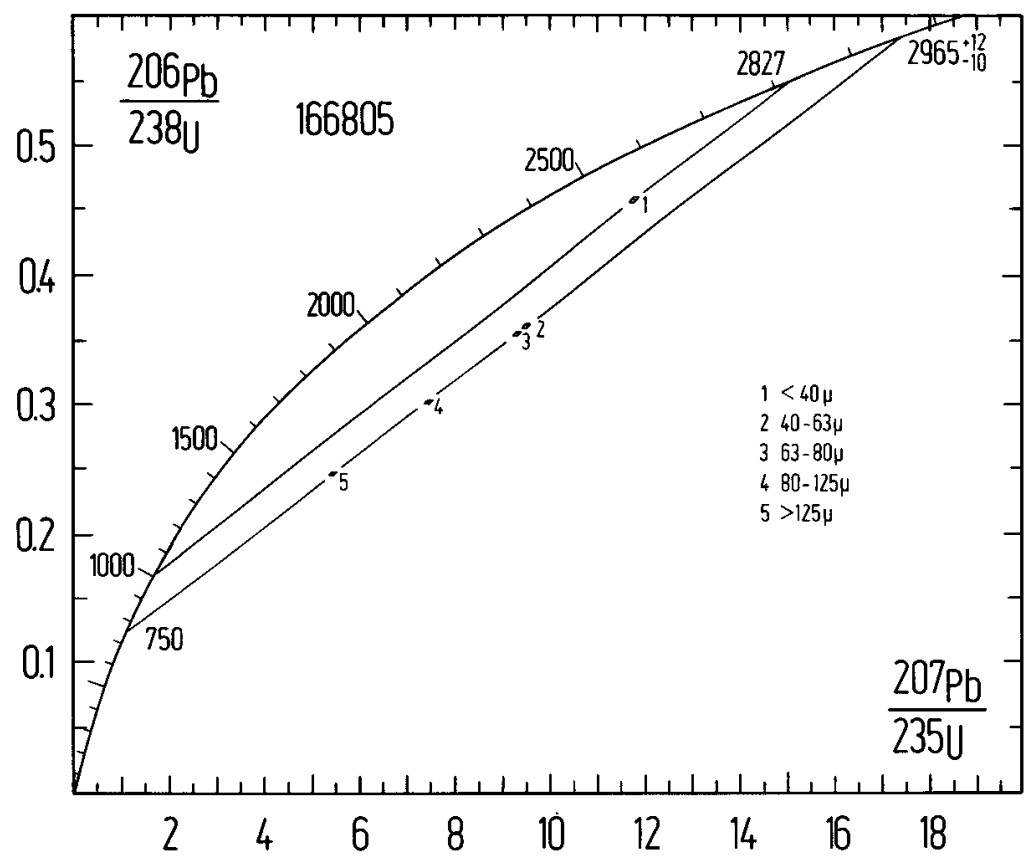

Fig. 3. Concordia plot of zircons from sample 166805, west of Harefjord.

carried out on a sample of the banded gneisses forming the country rock surrounding the augen gneiss in the same area.

Five zircon sieve fractions from the rock (GGU sample no 166805) have been analysed (Table 1), and the data are plotted in fig. 3. The data for the five sieve fractions show a systematic relationship between grain size and uranium concentration, the finest grain size having the lowest $U$ concentration, as is often characteristic for Archaean zircons. The four coarsest fractions form a discordia with intercepts at $750 \mathrm{Ma}$ and $2965 \mathrm{Ma}$. Although the four fractions show a considerable spread, the lower intercept age of $750 \mathrm{Ma}$ has no apparent geological significance, and the upper intercept age must therefore be regarded as a minimum age. An indication of a disturbed system is given by the data point for the sieve fraction $<40$ $\mu \mathrm{m}$, which plots clearly above the discordia defined by the other points suggesting a different evolution. If these zircons were formed during the main regional metamorphism, which in this area is considered to have taken place during a mid-Proterozoic (Grenville - c. $1100 \mathrm{Ma}$ ) orogenic event (Hansen et al., 1978; Henriksen, 1982) then a minimum age of at least 2825 $\mathrm{Ma}$ is obtained (fig. 3); the area was also subsequently affected by Caledonian metamorphism, and a new growth or episodic lead loss might have been superimposed on the zircons moving the data points to younger ages.

The deduced minimum ages for the zircons in the banded gneisses at Harefjord fall in the range 2825-2965 Ma, which supports the field evidence that the infracrustal rock units around Harefjord are part of the Flyverfjord complex. 


\section{References}

Hansen, B. T., Higgins, A. K. \& Bär, M.-T. 1978: Rb-Sr and U-Pb age patterns in polymetamorphic sediments from the southern part of the East Greenland Caledonides. Bull. geol. Soc. Denmark 27, $55-62$.

Hansen, B. T., Steiger, R. H. \& Higgins, A. K. 1981: Isotopic evidence for a Precambrian metamorphic event within the Charcot Land window, East Greenland Caledonian fold belt. Bull. geol. Soc. Denmark 29, $151-160$.

Henriksen, N. 1981: The Charcot Land tillite, Scoresby Sund, East Greenland. In Hambrey, A. J. \& Harland, W. B. (edit.) Earth's pre-Pleistocene glacial record, 776-777. Cambridge Univ. Press.

Henriksen, N. \& Higgins, A. K. 1976: East Greenland Caledonides. In Escher, A. \& Watt, W. S. (edit.) Geology of Greenland, 182-246. Copenhagen: Geol. Surv. Greenland.

Henriksen, N., Perch-Nielsen, K. \& Andersen, C. 1980: Descriptive text to 1:100 000 sheets Sydlige Stauning Alper $71 \varnothing .2 \mathrm{~N}$ and Frederiksdal $71 \varnothing .3 \mathrm{~N}$. Grønlands geol. Unders. $46 \mathrm{pp}$.

Higgins, A. K. 1982: Descriptive text to 1:100 000 sheets Charcot Land $71 \varnothing .4 \mathrm{~N}$ and Krummedal $71 \varnothing .4$ S. Grønlands geol. Unders. $26 \mathrm{pp}$.

Persson, P.-O., Wahlgren, C.-H. \& Hansen, B. T. 1983: U-Pb ages of Proterozoic metaplutonites in the gneiss complex of southern Wärmland, South-western Sweden. Geol. Fören. Stockh. Förh. 105, $1-8$.

Rex, D. C. \& Gledhill, A. 1974: Reconnaissance geochronology of the infracrustal rocks of Flyverfjord, Scoresby Sund, East Greenland. Bull. geol. Soc. Denmark 23, $49-54$.

Stacey, J. S. \& Kramers, J. D. 1975: Approximation of terrestrial lead isotope evolution by a two-stage model. Earth planet. Sci. Lett. 26, $207-221$.

Steck, A. 1971: Kaledonische metamorphose der praekambrischen Charcot Land Serie, Scoresby Sund, Ost-Grönland. Bull. Grønlands geol. Unders. 97, 69 pp. (also Meddr Grønland 192,3).

Steiger, R. H. \& Jäger, E. 1977: Subcommision on geochronology: convention on the use of decay constants in geo- and cosmochronology. Earth planet. Sci. Lett. 36, 359-362.

Steiger, R. H., Hansen, B. T., Schuler, C., Bär, M. T. \& Henriksen, N. 1979: Polyorogenic nature of the southern Caledonian Fold Belt on East Greenland: an isotopic age study. J. Geol. 87, 475 - 495.

York, D. 1969: Least squares fitting of a straight line with correlated errors. Earth planet. Sci. Lett. 5, $320-324$. 